\title{
Corticotrophin-releasing hormone inhibits insulin-like growth factor-I release from primary cultures of rat granulosa cells
}

\author{
A E Calogero, A Barreca ${ }^{1}$, N Burrello, I Palermo, G Giordano ${ }^{1}$, \\ R D'Agata and E Vicari
}

Section of Endocrinology, Andrology and Internal Medicine, Department of Biomedical Sciences, University of Catania, Catania, Italy
${ }^{1}$ Department of Endocrinology and Metabolism, University of Genoa, Genoa, Italy
(Requests for offprints should be addressed to A E Calogero, Cattedra di Endocrinologia, Ospedale Garibaldi, Piazza S Maria di Gesù, 95123 Catania, Italy;
Email: acaloger@unict.it)

\begin{abstract}
Corticotrophin-releasing hormone (CRH), a neuropeptide which modulates gonadal function during stress, is expressed by several cell types of the rat ovary and is able to suppress oestrogen release from rat granulosa cells. The mechanism of this effect is, however, not known. Since insulin-like growth factor (IGF)-I is produced by rat granulosa cells and exerts a synergistic role with FSH on granulosa cell steroidogenesis, we hypothesised that CRH may suppress oestrogen release from granulosa cells by inhibiting IGF-I release and/or stimulating the release of its binding protein (IGFBP-3). To test this hypothesis, granulosa cells were obtained from immature female Sprague-Dawley rats primed with diethylstilboestrol, and hormone concentrations were measured in the conditioned medium by radioimmunoassay. CRH suppressed oestrogen and IGF-I release stimulated by FSH used at a
\end{abstract}

concentration of $1 \mathrm{IU} / 1$, whereas it did not have any statistically significant effect on oestrogen and IGF-I release in basal conditions or in response to $5 \mathrm{IU} / 1 \mathrm{FSH}$. The suppressive effects of $\mathrm{CRH}$ on oestrogen and IGF-I release were antagonised by a selective $\mathrm{CRH}$ receptor antagonist. $\mathrm{CRH}$ had no effects on IGFBP-3 release. CRH did not have any effect on oestrogen release stimulated by increasing concentrations of IGF-I and its suppressive effect on FSH-stimulated oestrogen release was overcome by the addition of low doses of exogenous IGF-I. In conclusion, CRH suppressed the release of oestrogen and IGF-I, but not of IGFBP-3. Thus, the inhibitory effects of CRH on oestrogen release could be mediated, partly, by a suppression of the autocrine/paracrine action of IGF-I.

Journal of Endocrinology (2002) 174, 493-498

\section{Introduction}

Corticotrophin-releasing hormone (CRH), a 41-amino acid peptide secreted by the paraventricular nucleus of the hypothalamus, is the main activator of the hypothalamicpituitary-adrenal axis and it exerts a major role in coordinating the endocrine, autonomic and behavioural responses to stress (Chrousos \& Gold 1992). This neuropeptide also plays an important role in the suppression of the hypothalamic-pituitary-gonadal (HPG) axis during stressful events (see Rivier \& Rivest 1991 for review). Indeed, CRH has been shown to be capable of inhibiting the release of gonadotrophin-releasing hormone at the hypothalamic level (see Calogero et al. 1998 for review). This is not, however, the only mechanism through which this neuropeptide inhibits the function of the HPG axis. Experimental evidence suggests that CRH may also act as a local anti-reproductive factor in the male rat (Yoon et al. 1988, Ulisse et al. 1989). More recent findings have shown that $\mathrm{CRH}$ is also produced by the ovary where it is localised in theca cells surrounding follicles, stroma cells, mature oocytes within antral follicles and ovarian resident macrophages. In the developing corpora lutea, it is detectable in the cytoplasm of both small theca-derived and large granulosa-derived luteinized cells (Mastorakos et al. 1993, Muglia et al. 1994, Asakura et al. 1997). It has been shown to restrain the production of oestrogen by rat and human granulosa cells (Calogero et al. 1996, Ghizzoni et al. 1997). The mechanism(s) of this inhibition is, however, not well known.

In recent years, a large body of literature has highlighted the importance of insulin-like growth factors (IGFs) in regulating the development and the function of ovarian follicles under the modulatory effects of IGF binding proteins (IGFBPs). It has been shown that all components of the system are synthesised in ovarian follicles, thus revealing that IGFs and IGFBPs can act through an autocrine/paracrine mechanism in addition to the classical endocrine mechanism (see Giudice 1992 for review). IGF-I, a basic member of this family, is produced by the 
granulosa cells of the developing follicle in the rat (Oliver et al. 1989). In murine ovaries, besides a potent stimulatory effect on granulosa cell replication (Zhou et al. 1991), IGF-I also exerts a stimulatory effect on the synthesis of proteoglycans (Adashi et al. 1986) and on aromatase activity (Adashi et al. 1985a). Moreover, it has a synergistic role with follicle-stimulating hormone (FSH) on steroidogenesis and luteinizing hormone receptor induction (Adashi et al. 1985b,c), probably by stimulating FSH receptor gene expression in granulosa cells (Zhou et al. 1997). The fact that, using an in situ hybridisation technique, the mRNAs for IGFBP-2, -3 and -4 have been localised in the interstitial cells, corpora lutea, and atretic granulosa cells respectively, hints at a different regulation for each of these IGFBPs, which may have a role as autocrine/paracrine factors in modulating the local actions of the IGFs in the rat ovary (Nakatami et al. 1991). The effect of FSH on the production of IGFBPs by granulosa cells from immature oestrogen-primed rats has been shown to be dose- and time-dependent (Adashi et al. 1991). Indeed, high levels of FSH inhibit the local synthesis/ release of the IGFBPs which, in turn, have an inhibitory effect on IGF biological activity (Adashi et al. 1990, Barreca et al. 1996, Mason et al. 1998). The consequence is a great potentiation of the biological effect of FSH on follicular maturation.

The antithetical effects of CRH and IGF-I (Adashi et al. 1985a, Calogero et al. 1996) at the ovarian level led us to hypothesise that the suppressive effects of $\mathrm{CRH}$ on oestrogen release from granulosa cells may be due to an inhibition of IGF-I production and/or a stimulation of IGFBP-3 production. To test this hypothesis, we studied the effects of CRH on IGF-I and IGFBP-3 release into the conditioned medium of primary cultures of rat granulosa cells. We also evaluated the effect of increasing concentrations of CRH on IGF-I-stimulated oestrogen release.

\section{Materials and Methods}

\section{Rat granulosa cell culture}

Rat granulosa cells were cultured as previously reported (Calogero et al. 1996) with slight modifications. Briefly, intact female immature (25 days old) Sprague-Dawley rats (Charles River, Calco, CO, Italy) were implanted subcutaneously with 10-mm silastic capsules filled with diethylstilboestrol (DES) (Sigma Chemical Co., St Louis, MO, USA). Four days after the implantation, rats were killed by cervical dislocation and ovaries were removed for granulosa cell collection. Ovaries were decapsulated, follicles were punctured with 27-gauge hypodermic needles, and granulosa cells were expressed into McCoy's 5a medium (Life Technologies, Paisley, Strathclyde, UK) to make a single cell suspension which was used for control and experimental cultures. An aliquot was diluted with trypan blue stain and viable cells were counted with a haemacytometer. Cells were incubated in McCoy's 5a medium supplemented with $2 \mathrm{mmol} / \mathrm{l}$ L-glutamine, $200 \mathrm{U} / \mathrm{ml}$ penicillin, $200 \mu \mathrm{g} / \mathrm{ml}$ streptomycin sulphate, $0.5 \mu \mathrm{g} / \mathrm{ml}$ fungizone (Life Technologies), $10^{-6} \mathrm{~mol} / 1$ androstenedione, $10^{-7} \mathrm{~mol} / \mathrm{l}$ DES, $35 \mu \mathrm{g} / \mathrm{ml}$ methylisobutylxanthine (Sigma), and $37.5 \mathrm{ng} / \mathrm{ml}$ human chorionic gonadotrophin (hCG) (CR-127, NIDDK, Bethesda, $\mathrm{MD}$, USA). Cells were cultured for 6 days in a humidified $95 \%$ air-5\% $\mathrm{CO}_{2}$ incubator at $37^{\circ} \mathrm{C}$ with the following treatments: medium alone (control), medium containing human FSH (NIDDK, hFSH B-1, AFP-8792B), rat/ human CRH (Peninsula Laboratories Europe Ltd, St Helens, Merseyside, UK), $\alpha$-helical $\mathrm{CRH}_{9-41}$ (Peninsula Laboratories), and/or human recombinant IGF-I (Amersham International plc, Amersham Bucks, UK). To evaluate the effects of CRH on IGF-I and IGFBP-3 release, granulosa cells were plated onto $25-\mathrm{cm}^{2}$ flasks (Corning, Milan, Italy), at a density of $10^{6}$ cells $/ \mathrm{ml}$ (10 ml/flask). CRH was used at a concentration of $10^{-7} \mathrm{~mol} / \mathrm{l}$, a concentration known to be capable of suppressing FSH (1 IU/1)-stimulated oestrogen release by about 30\% (Calogero et al. 1996). Each experiment was performed in at least six different cultures. To evaluate the effects of IGF-I, FSH and/or CRH on oestrogen release, granulosa cells were plated onto 16-mm, 24-multiwell plates (Corning), at a density of 50000 cells/well $/ 0 \cdot 5 \mathrm{ml}$. Each experiment was performed in four different cultures. At the end of the culture period, the incubation medium was collected and centrifuged. The supernatant was stored at $-20{ }^{\circ} \mathrm{C}$ until assayed for IGF-I, IGFBP-3 and oestrogen concentration.

\section{Oestrogen measurement}

The concentration of oestrogen in the incubation medium was measured directly without prior extraction, by RIA (Calogero et al. 1996). Aliquots $(200 \mu \mathrm{l})$ of medium, diluted 1:100-1:200, or standard solutions were incubated with $100 \mu \mathrm{l}$ anti-oestrogen serum (final dilution 1:10 000), and $100 \mu \mathrm{l}\left[{ }^{3} \mathrm{H}\right] 17 \beta$-oestradiol (about 10000 c.p.m.) at $4{ }^{\circ} \mathrm{C}$ for $18-20 \mathrm{~h}$. Ice-cold charcoal-dextran was then added to achieve separation of bound from free labelled hormone. Tubes were centrifuged at $1500 \mathrm{~g}$ at $4{ }^{\circ} \mathrm{C}$ for $15 \mathrm{~min}$, and the supernatants were collected and counted in a $\beta$-counter after the addition of scintillation liquid. Total and nonspecific binding values were $33 \cdot 6 \pm 2 \cdot 1 \%$ and $2 \cdot 1 \pm 0 \cdot 1 \%$ respectively. Intra- and interassay coefficients of variation were $4 \cdot 5 \pm 0 \cdot 6 \%$ and $9 \cdot 3 \%$ respectively.

\section{IGF-I and IGFBP-3 measurements}

The media conditioned by rat granulosa cells were acidified by $18 \mathrm{~h}$ dialysis at $4{ }^{\circ} \mathrm{C}$ against $1 \mathrm{~mol} / 1$ acetic acid, lyophilised and resuspended with $0.1 \mathrm{~mol} / 1$ acetic 
acid- $0 \cdot 15 \mathrm{~mol} / 1 \mathrm{NaCl}(\mathrm{pH}$ of the mixture $<3$ ). IGF-I was separated from IGFBP by gel filtration on a Sephadex G-50 column $(1.6 \times 90 \mathrm{~cm})$ equilibrated with $0.1 \mathrm{~mol} / 1$ acetic acid- $0 \cdot 15 \mathrm{~mol} / 1 \mathrm{NaCl}, \mathrm{pH} 2 \cdot 75$. Fractions corresponding to $0-0 \cdot 20$ (corresponding to the IGFBP elution volume), $0 \cdot 21-0 \cdot 40,0 \cdot 41-0 \cdot 70$ (corresponding to the free IGF elution volume) and 0.71-1 partition coefficient between the liquid phase and the gel phase $\left(K_{\mathrm{av}}\right)$ were pooled, lyophilised, reconstituted in PBS and analysed for IGF-I and IGFBP-3 immunoreactivity.

The IGF-I contents of media were evaluated in the fractions eluted from the Sephadex G-50 column in the molecular weight range of the free peptide. IGF-I was measured by double-antibody RIA using immunochemicals and tracer provided by Medgenix (Fleurus, Belgium). The intra-assay and interassay coefficients of variation were 6 and $7 \cdot 5 \%$ respectively.

The IGFBP-3 contents of conditioned media were evaluated in the fractions eluted from the Sephadex G-50 column in the molecular mass range of more than $30 \mathrm{kDa}$. IGFBP-3 was measured by immunoassay using reagents and tracer provided by Bioclone Australia Pty Ltd (Narrickville, NSW, Australia). The intra-assay and interassay coefficients of variation were 4.25 and $6 \cdot 6 \%$ respectively.

\section{Data analysis}

Results, reported as means \pm S.E.M. throughout the study, are expressed as percentage of basal hormone production. Statistical evaluation was performed by one-way analysis of variance (ANOVA) followed by the Duncan's Multiple Range test. Correlation analysis was performed using Pearson's correlation test. Significance was accepted at a $P$ value lower than $0 \cdot 05$.

\section{Results}

\section{Effects of CRH on oestrogen, IGF-I, and IGFBP-3 release}

In basal conditions, granulosa cells released $1.26 \pm$ $0.03 \mathrm{ng} /$ well oestrogens, $7.92 \pm 1.47 \mathrm{ng} /$ flask IGF-I and $3 \cdot 61 \pm 0 \cdot 47 \mathrm{ng} /$ flask IGFBP-3. CRH at a concentration of $10^{-7} \mathrm{~mol} / 1$ suppressed FSH (1 IU/l)-stimulated oestrogen (Fig. 1, upper panel) and IGF-I (Fig. 1, lower panel) release, whereas it had no effects on the release of either hormone in basal conditions or following exposure to $5 \mathrm{IU} / 1 \mathrm{FSH}$. The amount of IGF-I released into the incubation medium correlated significantly with that of oestrogen $(r=0 \cdot 30, P=0 \cdot 02, n=58)$. To evaluate whether the suppressive effects of $\mathrm{CRH}$ were receptor-mediated, we incubated granulosa cells with a tenfold excess of the $\mathrm{CRH}$ receptor antagonist, $\alpha$-helical $\mathrm{CRH}_{9-41}$ which overcame the effects of CRH on both oestrogen and IGF-I release (Fig. 2). Since the antagonist alone did not have any
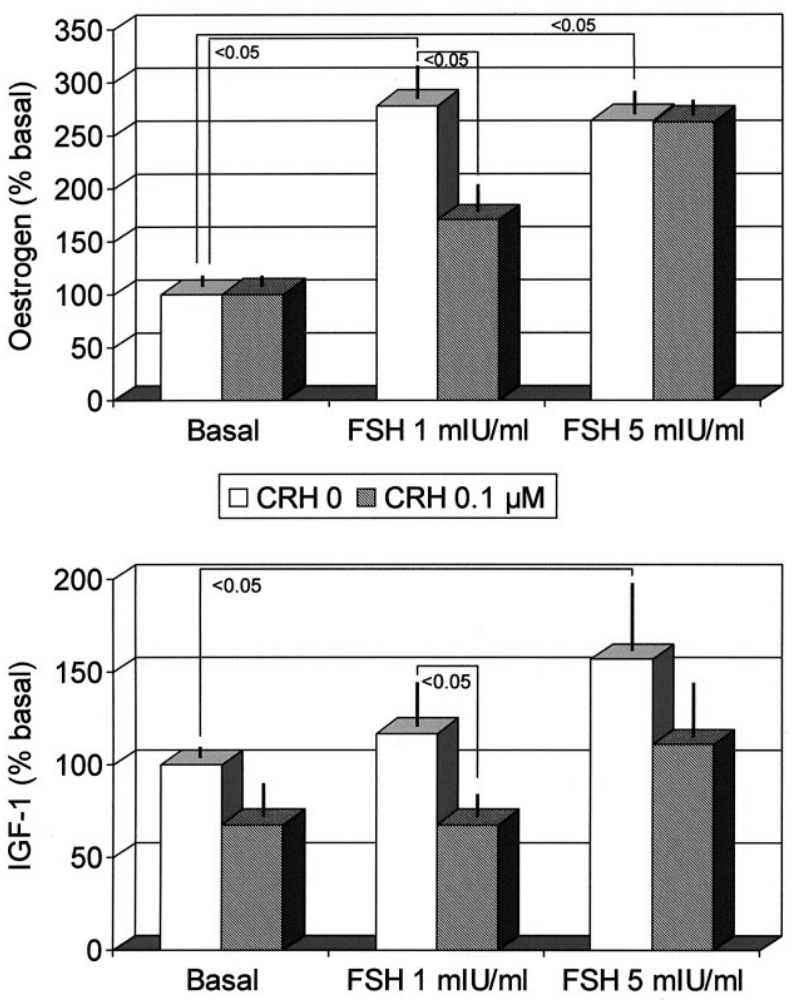

$\square \mathrm{CRH} 0 \square \mathrm{CRH} 0.1 \mu \mathrm{M}$

Figure 1 Effects of CRH on oestrogen (upper panel) and IGF-I (lower panel) release by rat granulosa cells under basal conditions and following administration of 1 or $5 \mathrm{mlU} / \mathrm{ml} \mathrm{FSH}$. CRH suppressed oestrogen and IGF-I release. Results are expressed as means \pm S.E.M.

effect on oestrogen or IGF-I release (data not shown), these data suggest that the suppressive effects of $\mathrm{CRH}$ on oestrogen and IGF-I release were receptor-mediated. $\mathrm{CRH}$ did not have any effect on IGFBP-3 release (data not shown).

\section{Effect of CRH on oestrogen release stimulated by IGF-I}

A preliminary dose-response study showed that IGF-I $(25,50$ and $100 \mathrm{ng} / \mathrm{ml})$ stimulated oestrogen release in a concentration-dependent manner. At the highest concentration tested, IGF-I was as effective as 1 IU/1 FSH (data not shown). We then tested the effects of $\mathrm{CRH}$ on the oestrogen release stimulated by these three concentrations of IGF-I. CRH at concentrations of $10^{-8}$ or $10^{-7} \mathrm{~mol} / 1$ did not have any effect on IGF-I-stimulated oestrogen release (Fig. 3). The addition of low concentrations of IGF-I ( 25 or $50 \mathrm{ng} / \mathrm{ml}$ ) was, on the other hand, able to overcome the suppressive effects of $\mathrm{CRH}$ on $\mathrm{FSH}$ (1 IU/l)-stimulated oestrogen release (Fig. 4), suggesting 

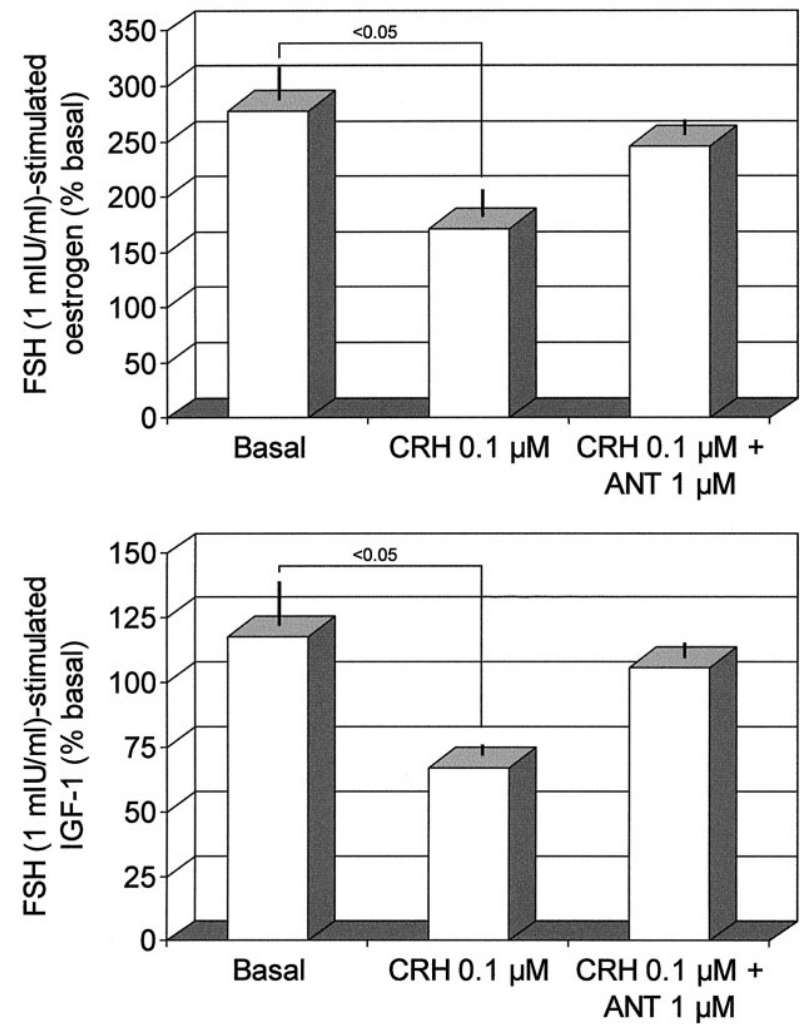

Figure 2 Effects of the $\mathrm{CRH}$ receptor antagonist $\alpha$-helical $\mathrm{CRH}_{9-41}$ (ANT) on FSH (1 IU/l)-stimulated oestrogen (upper panel) and IGF-I (lower panel) release. The suppressive effects of CRH on oestrogen and IGF-I release were receptor-mediated. Results are expressed as means \pm S.E.M. Basal=experiments without $\mathrm{CRH}$ and ANT.

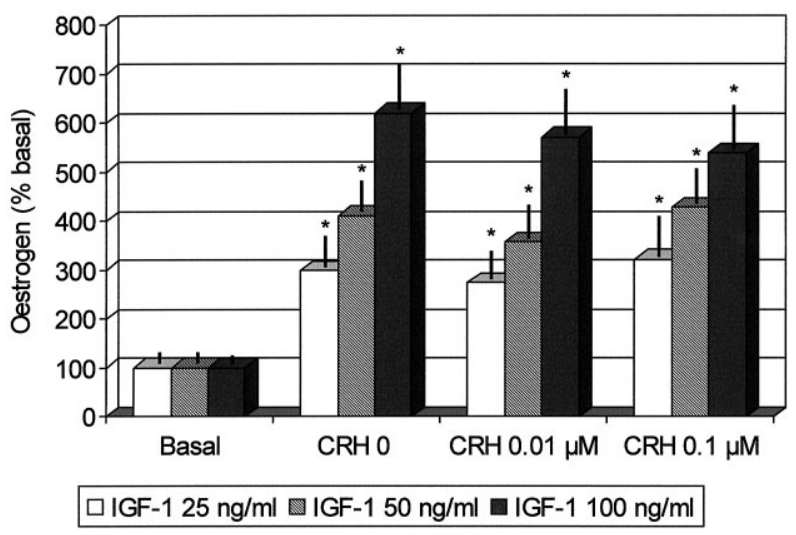

Figure 3 Effects of increasing concentrations of $\mathrm{CRH}$ on oestrogen release stimulated by increasing concentrations of IGF-I. CRH did not have any effect on IGF-I-stimulated oestrogen release. Results are expressed as means \pm S.E.M. Basal=experiments without IGF-I and $\mathrm{CRH} .{ }^{*} P<0.05$ compared with respective basal value.
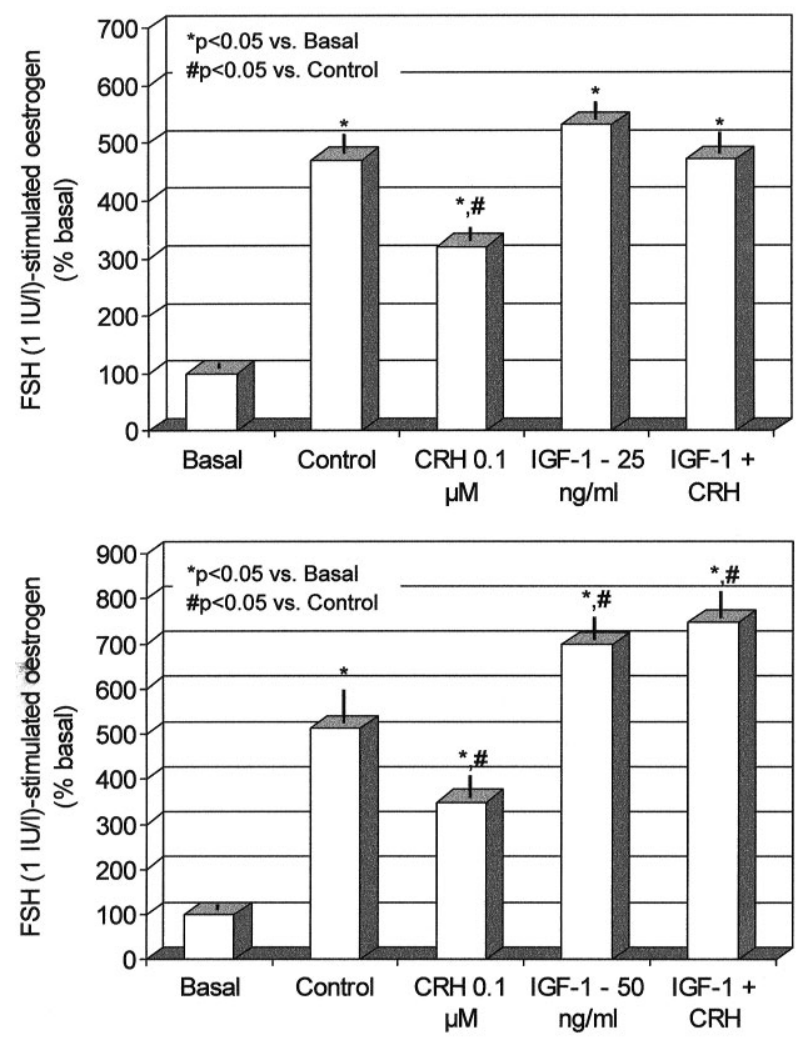

Figure 4 Effects of $25 \mathrm{ng} / \mathrm{ml}$ (upper panel) or $50 \mathrm{ng} / \mathrm{ml}$ (lower panel) IGF-I on the suppressive effects of $\mathrm{CRH}$ on FSH (1 IU/I)-stimulated oestrogen release. The exogenous addition of IGF-I overcame the suppressive effects of CRH. Results are expressed as means \pm S.E.M. Basal=experiments without FSH, CRH and IGF-I; Control=experiments with FSH $1 \mathrm{IU} / \mathrm{I}$ alone.

that the suppressive effect of $\mathrm{CRH}$ on oestrogen release may relate to the inhibition of endogenous IGF-I release.

\section{Discussion}

Immunoreactive $\mathrm{CRH}$ and $\mathrm{CRH}$ receptors have been found in rat ovaries (Mastorakos et al. 1993). Ovarian $\mathrm{CRH}$ is produced locally since both mouse and human ovarian tissue express CRH mRNA (Muglia et al. 1994, Asakura et al. 1997). By specific in situ hybridisation, Nappi and Rivest (1995) confirmed the presence of CRH receptors in the ovary and characterised them as type 1. These findings suggest that CRH may play an autocrine/ paracrine role on ovarian function. Indeed, the studies undertaken to evaluate the role, if any, of CRH on rat ovarian function have shown that the neuropeptide inhibits ovarian steroidogenesis. Preliminary studies showed that $\mathrm{CRH}$ suppresses the production of androsterone from ovarian cell dispersates and of progesterone from granulosa cells luteinized by pretreatment with FSH (Mastorakos 
et al. 1992). We have shown that $\mathrm{CRH}$ at elevated concentrations (i.e. $10^{-8}$ and $10^{-7} \mathrm{~mol} / \mathrm{l}$ ) inhibits FSHstimulated oestrogen production by rat granulosa cells, whereas at a lower concentration (i.e. $10^{-10} \mathrm{~mol} / \mathrm{l}$ ), it causes a rightward shift of the oestrogen dose-response curve to FSH (Calogero et al. 1996). The capability of $\mathrm{CRH}$ to suppress ovarian steroidogenesis has also been confirmed in human granulosa-luteal cells (Calogero et al. 1996, Ghizzoni et al. 1997). The mechanism(s) of this inhibition is, however, unclear. We found that $\mathrm{CRH}$ suppresses the activity of the enzyme aromatase from rat granulosa cells without affecting their intracellular content of cAMP, the second messenger of FSH (Catt \& Pierce 1986). Hence, it is not clear whether CRH acts directly on aromatase expression and/or function or whether it modulates other cAMP-independent cellular effects.

Because of the well-known stimulatory role of IGF-I on oestrogen release and aromatase activity in granulosa cells (Adashi et al. 1985a), we addressed the question whether $\mathrm{CRH}$ suppresses oestrogen release by interfering with the production of IGF-I from rat granulosa cells. The results of this study show that $\mathrm{CRH}$ is capable of inhibiting the production of IGF-I. The suppression of IGF-I release in the medium of incubation was completely abolished by the addition of a tenfold excess of the $\mathrm{CRH}$ receptor antagonist $\alpha$-helical $\mathrm{CRH}_{9-41}$, indicating that this effect was receptor-mediated. Thus, the effects of $\mathrm{CRH}$ on oestrogen production could be mediated, at least in part, by inhibiting the autocrine/paracrine action of IGF-I. This is further supported by the lack of CRH effect on oestrogen release stimulated by exogenously added IGF-I and by the finding that $\mathrm{CRH}$-induced suppression of FSH-stimulated oestrogen release was overcome by low concentrations of exogenously added IGF-I. IGFBP-3 is a protein which binds specifically IGF-I and with this mechanism it interferes with the effects of IGF-I. Indeed, the addition of IGFBP-3 to granulosa cell cultures inhibited the production of oestrogen in response to FSH (Ui et al. 1989). The lack of CRH effect on IGFBP-3 production suggested that this peptide acts on the ovarian IGF system in a rather selective manner.

In conclusion, CRH suppressed the production of IGF-I, but not of IGFBP-3, by rat granulosa cells in a $\mathrm{CRH}$ receptor-mediated fashion. This suggested that the suppressive effects of $\mathrm{CRH}$ on ovarian oestrogen release may, at least under these experimental conditions, be mediated by a decreased release of IGF-I. These data add further circumstantial evidence for a wider role of $\mathrm{CRH}$ on ovarian function since IGF-I modulates other ovarian functions.

\section{Acknowledgements}

The authors are indebted to Dr Raiti and Dr Parlow, National Institute of Digestive Disease and Kidney
(Bethesda, MD, USA) and National Hormone and Pituitary Program (Baltimore, MD, USA) for the generous supply of human FSH (NIDDK-hFSH-B-1, AFP-8792B) and hCG (NIDDK, CR-127).

\section{References}

Adashi EY, Resnick CE, Brodie AMH, Svoboda ME \& Van Wyk JJ $1985 a$ Somatomedin-C mediated potentiation of follicle-stimulating hormone-induced aromatase activity of cultured rat granulosa cells. Endocrinology 117 2313-2320.

Adashi EY, Resnick CE, Svoboda ME \& Van Wyk JJ 1985 b Somatomedin-C synergises with follicle-stimulating hormone in the acquisition of progestin biosynthetic capacity by cultured rat granulosa cells. Endocrinology 116 2135-2142.

Adashi EY, Resnick CE, Svoboda ME \& Van Wyk JJ 1985c Somatomedin-C enhances induction of luteinizing hormone receptors by follicle-stimulating hormone in cultured rat granulosa cells. Endocrinology 116 2369-2375.

Adashi EY, Resnick CE, Svoboda ME, Van Wyk JJ, Hascall VC \& Yanagishita M 1986 Independent and synergistic action of somatomedin-C in the stimulation of proteoglycan biosynthesis by cultured rat granulosa cells. Endocrinology 118 456-458.

Adashi EY, Resnick CE, Hernandez ER, Hurwitz A \& Rosenfeld RG 1990 Follicle-stimulating hormone inhibits the constitutive release of insulin-like growth factor binding proteins by cultured rat ovarian granulosa cells. Endocrinology 126 1305-1307.

Adashi EY, Resnick CE, Hurwitz A, Ricciarelli E, Hernandez HR \& Rosenfeld RG 1991 Ovarian granulosa cell-derived insulin-like growth factor binding proteins: modulatory role of follicle-stimulating hormone. Endocrinology 128 754-760.

Asakura H, Zwain IH \& Yen SSC 1997 Expression of genes encoding corticotropin-releasing factor (CRF), type 1 CRF receptor, and CRF-binding protein and localization of the gene products in the human ovary. Journal of Clinical Endocrinology and Metabolism 82 2720-2725.

Barreca A, Artini PG, Cesarone A, Arvigo M, Genazzani AR, Giordano G \& Minuto F 1996 Interrelationships between FSH and the IGF-IGFBPs system in human granulosa cells (GC) in culture. Journal of Endocrinological Investigation 19 35-42.

Calogero AE, Burrello N, Negri-Cesi P, Papale ML, Palumbo M, Cianci A, Sanfilippo S \& D'Agata R 1996 Effects of corticotropin-releasing hormone on ovarian estrogen production in vitro. Endocrinology 137 4161-4166.

Calogero AE, Bagdy G \& D’Agata R 1998 Mechanisms of stress on reproduction: evidence for a complex intra-hypothalamic circuit. Annals of the New York Academy of Sciences 851 364-370.

Catt KJ \& Pierce JG 1986 Gonadotropic hormones of the adenohypophysis. In Reproductive Endocrinology: Physiology, Pathophysiology and Clinical Management, edn 2, pp 75-184. Eds SSC Yen \& RB Jaffe. Philadelphia: WB Saunders Co.

Chrousos GP \& Gold PW 1992 The concepts of stress and stress system disorders. JAMA 267 1244-1252.

Ghizzoni L, Mastorakos G, Vottero A, Barreca A, Furlini M, Cesarone A, Ferrari B, Chrousos GP \& Bernasconi S 1997 Corticotropinreleasing hormone $(\mathrm{CRH})$ inhibits steroid biosynthesis by cultured human granulosa-lutein cells in a CRH and interleukin-1 receptor-mediated fashion. Endocrinology 138 4806-4811.

Giudice LC 1992 Insulin-like growth factors and ovarian follicular development. Endocrine Reviews 13 641-669.

Mason HD, Cwyfan-Hughes S, Holly JMP \& Franks S 1998 Potent inhibition of human ovarian steroidogenesis by insulin-like growth factor binding protein-4 (IGFBP-4). Journal of Clinical Endocrinology and Metabolism 83 284-287. 
Mastorakos G, Kokia E, Patchev V, Webster EL, Redwine J, Adashi EY \& Chrousos GP 1992 Presence of immunoreactive CRH and $\mathrm{CRH}$ binding sites, and evidence for auto/paracrine action of this neuropeptide in the rat ovary. Program of the 74th Annual Meeting of the Endocrine Society, San Antonio, TX, USA p 246 (Abstract).

Mastorakos G, Webster EL, Friedman TC \& Chrousos GP 1993 Immunoreactive corticotropin-releasing hormone and its binding sites in the rat ovary. Journal of Clinical Investigation 92 961-968.

Muglia LJ, Jenkins NA, Gilbert DJ, Copeland NG \& Majzoub JA 1994 Expression of the mouse corticotropin-releasing hormone gene in vivo and targeted inactivation in embryonic stem cells. Journal of Clinical Investigation 93 2066-2072.

Nappi R \& Rivest S 1995 Stress-induced genetic expression of a selective corticotropin-releasing factor-subtype within the rat ovaries: an effect dependent on the ovulatory cycle. Biology of Reproduction 53 1417-1428.

Nakatani A, Shimasaki S, Erickson GF \& Ling N 1991 Tissue specific expression of four insulin-like growth factor-binding proteins $(1,2$, 3, and 4) in the rat ovary. Endocrinology 129 1521-1529.

Oliver JE, Timothy AJ, Powell JF, Wilson CA \& Clayton RM 1989 Insulin-like growth factor I gene expression in the rat ovary is confined to the granulosa cells of developing follicles. Endocrinology 124 2671-2679.
Rivier C \& Rivest S 1991 Effects of stress on the activity of the hypothalamic-pituitary-gonadal axis: peripheral and central mechanisms. Biology of Reproduction 45 523-532.

Ui M, Shimonaka M, Shimasaki S \& Ling N 1989 An insulin-like growth factor-binding protein in ovarian follicular fluid blocks follicle-stimulating hormone-stimulated steroid production by ovarian granulosa cells. Endocrinology 125 912-916.

Ulisse S, Fabbri A \& Dufau ML 1989 Corticotropin-releasing factor receptors and actions in rat Leydig cells. Journal of Biological Chemistry 264 2156-2163.

Yoon DJ, Sklar C \& David R 1988 Presence of immunoreactive corticotropin-releasing factor in the rat testis. Endocrinology 122 759-761.

Zhou J, Chin E \& Bondy CA 1991 Cellular pattern of IGF-I and IGF-I receptor gene expression in the developing and mature follicle. Endocrinology 129 3281-3288.

Zhou J, Kumar TR, Matzuk MM \& Bondy CA 1997 Insulin-like growth factor-I regulates gonadotropin responsiveness in the murine ovary. Molecular Endocrinology 11 1924-1933.

Received 7 May 2002

Accepted 14 May 2002 